\title{
Emevî Dönemine Ait Dînâr ve Dirhemlerden Örnekler *
}

\section{Dinar and Dirhams Examples From The Ummayad Period}

\section{Emre GÜNAYa}

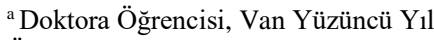
Üniversitesi, Van, Türkiye, numismaticstudies@outlook.com, ORCID: 0000-0003-2727-3087

\begin{abstract}
ÖZ
İslam'ın tebliğinden Hulefâ-yi Râşidîn Dönemine kadar (610-661) İslâmi tarzda sikke darp edilmemiştir. Bu tarih aralığında, Bizans dinârları ve İran dirhemlerinin kullanılmasına devam edilmiştir. İslâmi karakterde ilk sikkelerin darbını; 661-750 yılları arasında Avrupa'dan Asya'ya kadar geniş bir coğrafyada hâkimiyet sağlayan, İslam tarihinin ilk hânedan devleti olan Emevîler gerçekleştirmiştir. İslâm dünyasının kuvvetini ve bağımsılı̆ğını simgeleyen bu sikkelerin malzemesi, tekniği ve üzerinde yer alan düzenlemeler değerlendirildiğinde Emevîlerin ekonomik durumu, siyasi yapısı, yönetim biçimi ve sanatsal üslubu hakkında önemli bilgilere ulaşılmaktadır. $\mathrm{Bu}$ bağlamda çalışma, Zeno.ru arşivinde bulunan Emevî Dönemine ait on sekiz sikke örneğinin kronolojik olarak hâlifelerin saltanat tarihlerine göre incelenmesi, tanıtılması ve değerlendirilmesi amaçlanmaktadır.
\end{abstract}

Anahtar Kelimeler: Sikke, Emevî, Hâlife, Dînar, Dirhem.

\begin{abstract}
The coins which are Islamic syle were not minted from the time of the preaching of islam to the period of Hulefa-yi Raşidin (610-661). İt was continued to use Byzantine dinars and Iranian dirhams in this date range. The minting of the first coins of Islamic character are created by the Umayyads Which were the first dynastic state in the history of Islam, ruled over a wide geography from Europe to Asia Between 661 and 750. When the material, technique and arrangements on these coins, which symbolize the strength and independence of the Islamic world, are evaluated, important information is obtained about the economic situation, political structure, management style and artistic style of the Umayyads. In this context, the purpose of this article is to examine, introduce and evaluate the eighteen coin samples of the Umayyad Period which are found in the zeno.ru archive chronologically in accordance with the reign dates of the caliphs.
\end{abstract}

Keywords: Coins, Ummayad, Dinar, Dirham.

\footnotetext{
* Bu makalede bilimsel araştırma ve yayın etiği ilkelerine uyulmuştur. / In this article, the principles of scientific research and publication ethics were followed.

* Çalışmaya konu olan Emevî Dönemine ait dinar ve dirhemlerin araştırılması için kullanım iznini sağlayan Zeno.ru (www.zeno.ru) arşivi ile sikke çizimlerini gerçekleştiren Uzm Sanat Tarihçi Rahime Gökçe'ye teşekkürlerimi sunarım.

Attf-Reference: Günay, E. (2021). Emevî Dönemine Ait Dînâr ve Dirhemlerden Örnekler. Bitlis Eren Üniversitesi Sosyal Bilimler Dergisi, 10 (2), 9-29.
} 


\section{GíRiş}

\subsection{Sikkenin Tanımı, Darphane ve Darp Tekniği}

Kelime kökeni Arapçadan gelen sikke, ticarette ve günlük alışverişlerde ödeme aracı olarak kullanılan genellikle yuvarlak biçime sahip madeni bir disktir. Ağırlık ölçüleri önceden ayarlanan sikkelerin iki yüzü vardır: Ön ve Arka yüz. Ana yüz, daima ön yüzdür. Burada sikkeyi darp ettiren hükümdarın arması veya yazısı bulunmaktadır (Tekin, 2009: 179; Karwiese, 2004: 18).

Sikkenin darp edildiği atölyeye darphâne; malzeme, bilgi, teknik ve kuralların gerektirdiği basma işlemine darp denmektedir (Karakoç, 2021: 14). Darphâneler nispeten sade atölyelerdir. Mekanik sistem olmadığ́ için bütün işlemler elle yapılırdı. Darphâneler içerisinde, üstünde darp işleminin gerçekleştiği bir örs; sikke pulunu ısıtmak için bir ocak; bu pulları ağırlık ölçümleri için kullanılan bir terazi; kalıp hazırlamada kullanılan aletler; 1sıtılan pulu örs üzerindeki kalıp üstüne yerleştirmek için maşa ve çekiç bulunurdu (Demirel Gökalp, 2009: 6). Darp işlemine, sikkenin ön ve arka yüzüne işlenecek resim ve yazıların kalıplara ters olarak nakşedilmesi ile başlanırdı. Ön yüz kalıbı, örs üstüne sabitlenerek; sikke olacak madeni pul ısıtılarak bu kalıbın üzerine yerleştirilir; arka yüzü meydana getiren üst kalıp ise 1sıtılmış madenin üzerine konarak çekiç darbesiyle kalıpların üstündeki negatif resim ve yazılar pulun üstüne geçerdi (Erdoğan, 2015: 28). (Çizim: 1-2)

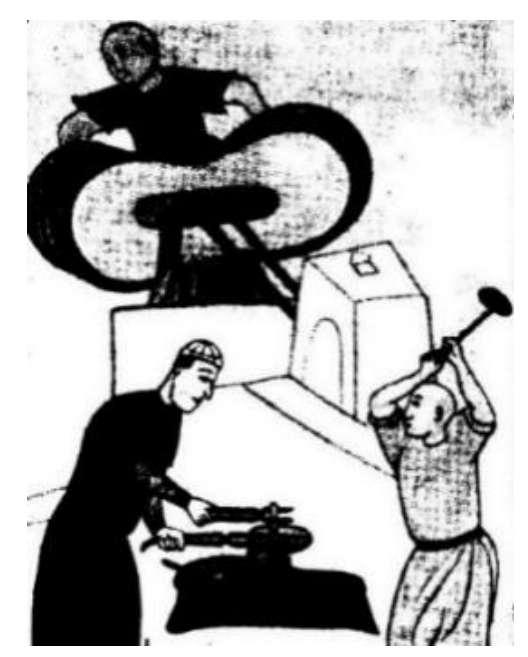

Çizim 1:

Darphanede Sikke Üretimi

(Pamuk, 2000, s. XIV)

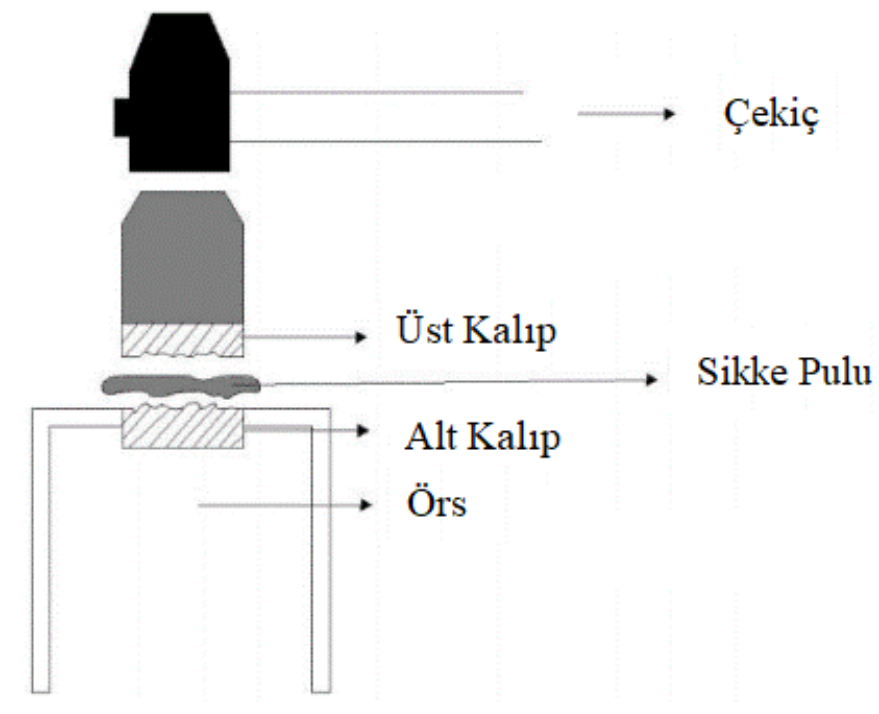

Çizim 2:

Çekiç ile Darp Basım Düzeneği

(Günay, 2019, s. 194)

\section{2.İslam Öncesi Arap Yarımadasında ve Emevîlerde Sikke Kullanımı}

Arap Yarımadası olarak adlandırılan coğrafya, Kızıldeniz'den Basra Körfezine, Fırat Nehrinden Hint Okyanusuna kadar uzanan bir bölgeyi kapsamaktadır. Arap Yarımadası önemli geçiş yolları üzerinde bulunması nedeniyle ticaret ağının merkezi konumunda bulunur. Bu güzergâh üzerinden çeşitli madenler, ipekler, süs eşyaları ve baharatlar gibi birçok ürün taşınmıştır (Şimşir, 2017: 271-272). Bu ürünler, çağın ve coğrafyanın koşulları dikkate alındığında yoğun bir şekilde alış-verişlerle el değiştirmiştir. Cahilîye Döneminde gerçekleşen bu ticari faaliyetlerde Araplar ticarî ilişkilerde bulundukları devletlerin sikkelerini geçerli sayıyor ve bunları kullanıyorlardı (Sahillioğlu,1993: 501; Bal, 2014: 115). Bu sikkeler; Doğu Roma'nın Mağribiye, Himyerîye, Kayseriye ve Herakliye, İran'ın ise; Vâfiye, Taberiye ve Bağliye'leridir (Kalkan, 2019: 85).

Cahîliye Döneminden sonra Hz. Muhammed sikke darp ettirmedi. Bu tarihte kullanılan sikkeler, yukarıda belirtildiği gibi Araplar arasında geçerli olan sikkelerdi. Hz. Muhammed'in 610-632 yılları arasında Mekke ve Medine'de gayrimüslimlerle sürekli mücadele içerisinde olması ve İslam dininin hükümlerini yayma gayreti, sikke darp ettirme veya kullanılan sikkelerin değiştirilmesi gibi çalışmalara zaman ayıramamasına neden olmuştur. Hz. Ebû Bekir'in 632-634 yılları arasındaki kısa hâlifelik döneminde sikke sistemini düzenleyecek imkânı bulamamıştır. Hz. Ebû Bekir'de Hz. Muhammed Döneminde tedavülde bulunan sikkeleri değiştirmeyerek onları kullanmıştır. Hz. Muhammed ve Hz. Ebû Bekir Döneminde farklı ağırlıklarla kullanılan dirhemler, Hz. Ömer'in hâlifeliğinin ilk yıllarında da aynı şekilde kullanılmasına devam edilmiştir. Ancak İslâm devletinin topraklarının genişlemesiyle birlikte büyüyen ticaret ağlarında bu çeşitli dirhemler, malların alımı ve satımı sırasında anlaşmazlıklara neden oluyordu. Hz. Ömer, bu sorunların ortadan kaldırılması için sikkelerin ölçüleri üzerinde değişikliklerde bulundu. Hz. Osman Döneminde, üzerinde 'Allahu Ekber' yazılı bir sikke darp edildi. Bu sikkeler, İslâm devletinin resmî sikkesi değildir. İdareciler tarafından darp edilen bu sikkeler bazı devlet işlerinde kolaylık sağlayan mahallî sikkelerdir. Hz. Ali Döneminde de Hz. Osman'ın mahalli sikkelerinden darp edilmiştir. Bu sikkelerin üzerinde "Bismillahi Rabbî” veya “ Veyullah" yazılı olduğu aktarılmaktadır (Damalı, 2001: 15-17; Artuk \& Artuk, 1971: XXXIII-XXXIV; Uslu, 2014: 31-32). Hulefâ-yi Râşidîn Döneminden sonra bu formda sikke uygulamaları; Emevî hâlifesi Muaviye b. Ebu Süfyan, (Foto.1) Abdülmelik b. Mervan'ın hilafetinden önce hilafetini açıklamış olan Abdullâh b. Zübeyr ve Hâricî kuvvetlerinin lideri Katarî b. Fucâe tarafından devam ettirildi. (Emanet, 2014: 256-257; Erkoçoğlu, 2007: 173-174). 
Yukarıda belirtilen İslâm'ın ilk dönemlerinde ticari faaliyetlerde dolaşımda bulunan ve büyük ilgi gören bu sikkeler, Emevî hâlifesi Abdülmelik b. Mervan'ın 697 senesinde gerçekleştirdiği sikke reformuna kadar yoğunlukla kullanıldı (Aydoğdu, 2018: 56).

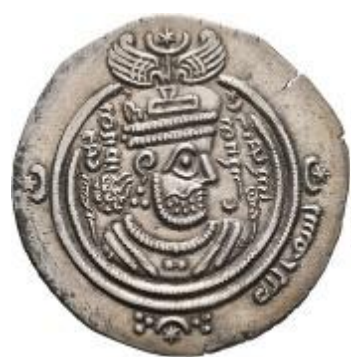

Foto. 1a: Ön Yüz

I. Muâviye b. Ebû Süfyan Döneminde (M.661-680) Arap - Bizans Tipinde Darp Ettirilen Emevî Dirhemi. Taçlı İmparator Tasviri. 4.00 gr (www.coinarchives.com)

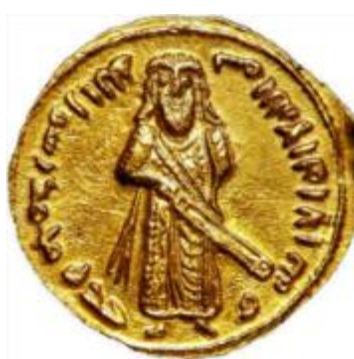

Foto. 2a: Ön Yüz

\section{Abdülmelik b. Mervan Döneminde (M.685-705) Arap - Bizans Tipinde Darp} Edilen Emevî Dinarı. Ayakta İmparator Tasviri. 4.50 gr (www.metmuseum.org)

Abdülmelik b. Mervân'da, hâlifeliğinin ilk dönemlerinde Hz. Muhammed ve Hulefâ-yi Râşidîn Döneminde olduğu gibi Bizans dinarları ile İran dirhemlerini kullanmıştır. (Yiğit, 1995: 103). Ancak bu sikkelerin kullanılması bazı sorunlara neden olmuştur (Dursun, 1988: 269). Bu sorunların en başında, İslâm ülkesinin çok geniş sınırları içerisinde farklı ölçülerde sikkelerin olması, mâli işlerde özellikle harâcların ve cizyelerin alınmasında aksaklıkların yaşanması ve buna bağlı olarak merkezî otoritenin siyasi olarak zayıflaması gelmekteydi (Erkoçoğlu, 2007: 175.

Abdülmelik b. Mervân'ın sikke darp ettirme ihtiyacını neden duyduğu konusunda İslam tarihçileri farklı görüşler bildirmektedir. İbn-i Esir “el-Kâmil fi’t Tarih” adlı kitabında Abdulmelik b. Mervân’ın Bizans İmparatoru ile yaptı̆̆ yazışmaların başında Kuran-1 Kerim'in İhlâs Suresi 1. Ayetini ve Hz. Muhammed'in hadîs-i şeriflerinin kullanılmasına sinirlenen Bizans İmparatorunun Abdulmelik b. Mervân'a yazdığı bir mektuba bağlamaktadır. Mektupta Bizans İmparatoru, Abdulmelik b. Mervân'a hitaben: "Kendisine bir daha böyle şeylerden bahsetmemesini, ĕger bir daha böyle ifadelerden bahsederse, sikkelerin üzerinde peygamberi kötüleyen yazılar yazacağını söyler'”. Abdulmelik b. Mervân, bu durumu Halid b. Yezid b. Muaviye'ye söyler. O da Bizans sikkelerini yasaklamasını ve üzerinde Allah'ın adının zikredildiği dinar ve dirhemleri darp etmesini tavsiye eder. Bu konu hakkında farklı bir görüş ise Makrizî’ye aittir. Makrizî’ye göre; Halid b. Yezid b. Muaviye, Abdulmelik b. Mervân'a “Ey Emîru'l Mü'minîn, ehli kitap âlimlerinin bildirdiğine göre hükümdarların içinde en uzun ömürlü olanların, sikkelerin üzerinde Allah'ı takdis edenler olduğunu söylemişlerdir” diye buyurmuştur. Bunun üzerine Abdulmelik b. Mervân'ın ilk İslamî sikkeyi basmaya karar verdiği belirtilmektedir (Emanet, 2014: 258).

697 yılı gelindiğinde, Abdülmelik b. Mervân'ın para reformunu gerçekleştirecek şartlar oluşmuş, İslâm devletinin sembollerini taşıyan ve kuvvetli propagandasını yapacak olan sikkelerin darp ettirme zamanı gelmiştir (Aydoğdu, 2018: 7).

Darphanelerde, hâlife adına özgün sikke darp ettirmek isterken ortaya çıkabilecek karışıklıkları engellemek için sikkeler üzerindeki değişiklikler aşamalı bir şekilde gerçekleştirilmiştir (Sivrioğlu, 2014: 6).

Abdülmelik b. Mervan'ın para reformunda beş evre tespit edilmiştir:

- I. evrede; 693 yılında darp ettirdiği dinarın üzerindeki Hristiyanlık işaretlerinden haç ve merdiveni muhafaza etmiş; ancak 21 sayısına tekabül eden B-I harfleri Bizans dinarının aksine I-B olarak yer değiştirmiştir.

- II. evrede; sikkenin arka yüzündeki haç işareti tahrif edilerek T harfi şeklini almıştır.

- III. evrede; haç işareti değiştirilmiş ve sikkenin kenarına kûfi hatla "Lâ ilâhe illâllahu vahdehû lâ şerike leh" ibaresi yazılmıştır. Bu aşamada Hareklius’un resmi muhafaza edilmiştir.

- IV. evrede; Abdülmelik bin Mervân, Bizans İmparatoru Heraklius’un resminin yerine kendi resmini koydurmuştur. Halîfe bu resimde kûfiye olarak isimlendirilen elbiseyi giymiş, elinde kılıcını sarkıtmış ve uzun sakallı olarak görülmektedir. Bu resmin çevresinde ise "Bismillâhi lâ ilâhe illâllâhu vahdehû Muhammed Resûlullâh" yazılıdır. (Foto.2)

- V. evrede; sikkelerin üzerinden bütün tasvirler kaldırılarak Arapça sikkenin darp bilgileri ve Kuran-1 Kerim'den ayetler işlenmiştir (Erkoçoğlu, 2007: 177).

697 yılında tamamlanan reformun son evresinden itibaren Emevî Devleti sınırları içerisinde bulunan darphanelerde İslâmi tarzda sikkeler darp edilmeye başlanmıştır (Aykut, 1982: 6). Abdülmelik b. Mervan, sikkeler üzerindeki bu yeniliklerle İslâm'ın zaferini ve Hz. Muhammed'in peygamberliğini ilan ederken Hıristiyan inançlarının da açıkça reddini bildiriyordu (Bacharach, 2004: 72). 


\section{EMEVÎ DÖNEMINNE AİT DÎNÂR VE DİRHEMLERDEN ÖRNEKLER}

Örnek

Envanter No

Darp Ettiren Hâlife

Darp Tarihi

Darp Yeri

Ölçü Birimi
$: 1$

: Zeno.ru: \#165977

: Abdülmelik b. Mervân

: H.78 - M.697/698

: Ermeniye

: 2.77 gr / Dirhem

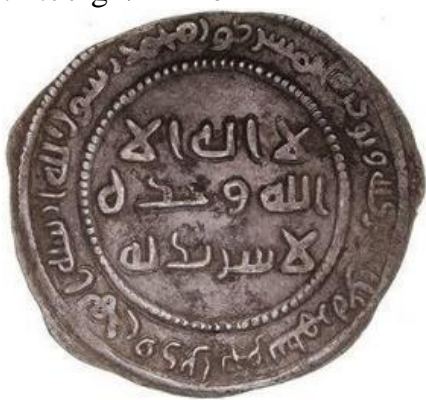

Foto.3a:

Örnek 1'in Ön Yüzü

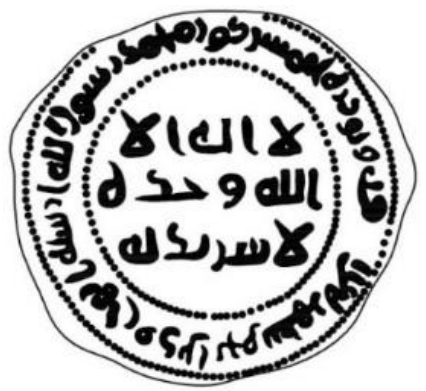

Cizim 3a:

Örnek 1'in Ön Yüzü

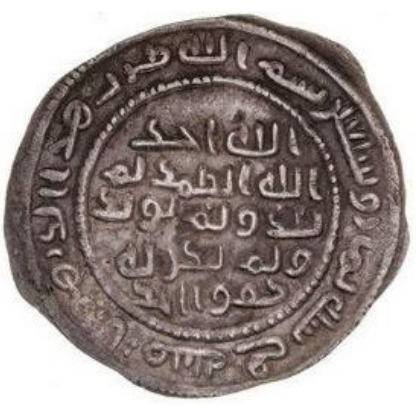

Foto.3b:

Örnek 1'in Arka Yüzü

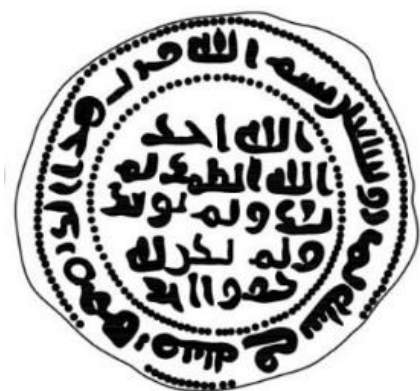

Çizim 3b:

Örnek 1'in Arka Yüzü

\section{Ön Yüz Okunuşu:}

Ortasinda:

Transkripsiyonu: Lâ ilâhe illa'llah vahdehu lâ şerike leh.

Anlamı: Allah'tan başka ilah yoktur, O birdir ve O'nun ortağı yoktur.

Etrafinda:

محمد رسول الله ارسله بالهُى ودين الحق ليظهره على الدين كله ولو كره المشركون Transkripsiyonu: Muhammedü’n Resûlu'llah. Ersele bil hudâ ve dînil hakkı li yuzhirehu aled dîni kullihî ve lev kerihel muşrikûn.

Anlamı: Muhammed Allah'ın elçisidir. O, Allah'a ortak koşanlar hoşlanmasalar bile dinini, bütün dinlere üstün kılmak için, peygamberini hidayetle ve hak dinle gönderendir.

\section{Arka Yüz Okunuşu:}

Ortasinda:

الله احد الله الصمد لم يلد ولم يولد ولم يكن له كفوا احد Transkripsiyonu: Allâhu ehad Allâhu's samed lem yelid ve lem yûled. Ve lem yekun lehû kufuven ahad.

Anlamı: Allah tektir. Allah Samed'dir. Ondan çocuk olmamıştır. Kendisi de doğmamıştır. Hiçbir şey O'na denk ve benzer değildir.

Etrafinda:

بسم الله ضرب هذا الدرهم بارمنية في سنة ثمان وسبعين

Transkripsiyonu: Bismillâh duribe haze'd dirhem bi-Ermeniye fi sene semân seb'în.

Anlamı: Allah'ın adıyla bu dirhem yetmiş sekiz senesinde Ermeniye darp edildi.

Örnek

Envanter No

Darp Ettiren Hâlife

Darp Tarihi

Darp Yeri

Ölçü Birimi
$: 2$

: Zeno.ru: \#260090

: Abdülmelik b. Mervân

: H.78 - M.697/698

: Bilinmiyor

: 4.21 gr / Dînar 


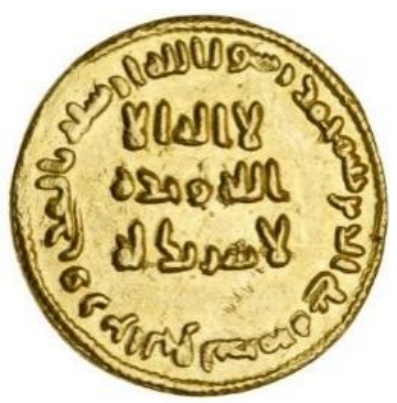

Foto.4a:

Örnek 2'in Ön Yüzü

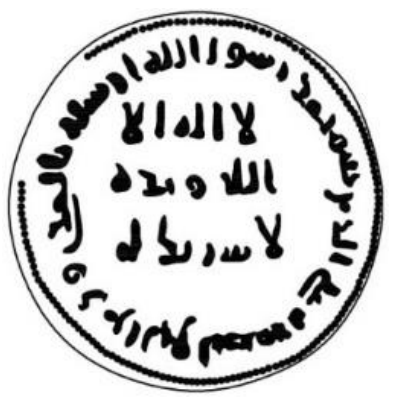

Çizim 4a:

Örnek 2'in Ön Yüzü

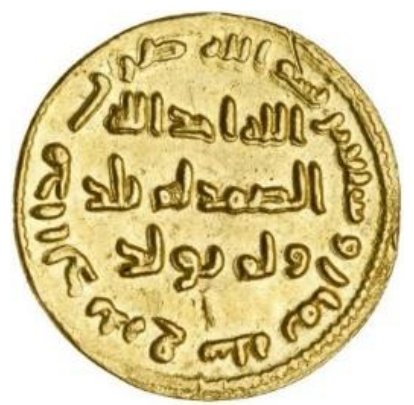

Foto.4b:

Örnek 2'in Arka Yüzü

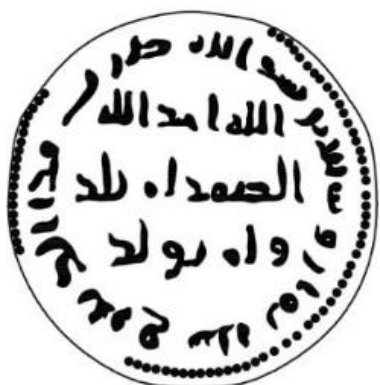

Çizim 4b:

Örnek 2'in Arka Yüzï

\section{Ön Yüz Okunuşu:}

Ortasinda:

Transkripsiyonu: Lâ ilâhe illa'llah vahdehu lâ şerike leh.

Anlamı: Allah'tan başka ilah yoktur, O birdir ve O'nun ortağı yoktur.

Etrafinda:

محمد رسول الله ارسله بالهـى ودين الحق ليظهره على الدين كله

Transkripsiyonu: Muhammedü'n Resûlu'llah. Ersele bil hudâ ve dînil hakkı li yuzhirehu aled dîni kullihî.

Anlamı: Muhammed Allah’ın elçisidir. Bütün dinlere üstün kılmak için, peygamberini hidayetle ve hak dinle gönderendir.

\section{Arka Yüz Okunuşu:}

Ortasinda:

الله احد الله الصمد لم يلا ولم يولد

Transkripsiyonu: Allâhu ehad Allâhu's samed lem yelid ve lem yûled.

Anlamı: Allah tektir. Allah Samed'dir. Ondan çocuk olmamıştır. Kendisi de doğmamıştır.

\section{Etrafinda:}

Transkripsiyonu: Bismillâh duribe haze'd dinar fî̀ sene seman seb'în.

Örnek

Envanter No

Darp Ettiren Hâlife

Darp Tarihi

Darp Yeri

Ölçü Birimi

$: 3$

: Zeno.ru: \#38032

: Abdülmelik b. Mervân,

: H.81 - M.700/701

: Nişabur

: 2.64 gr / Dirhem

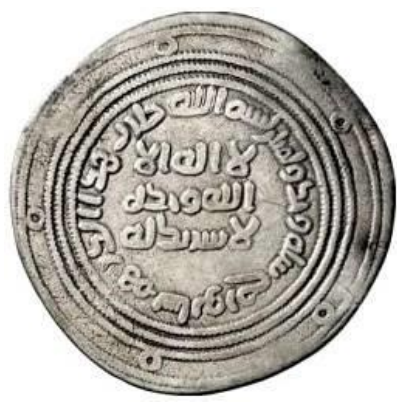

Foto.5a:

Örnek 3'ün Ön Yüzü

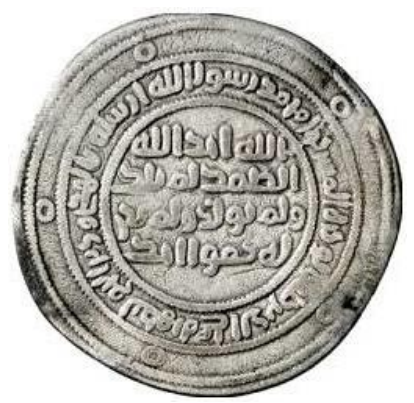

Foto.5b:

Örnek 3'ün Arka Yüzü 


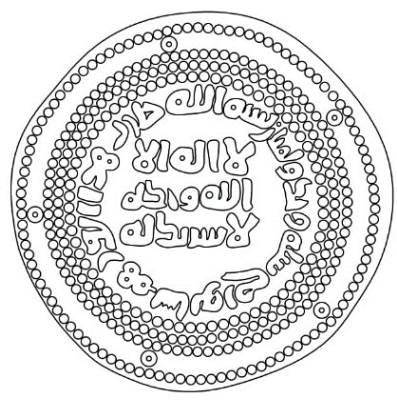

Çizim 5a:

Örnek 3'ün Ön Yüzü

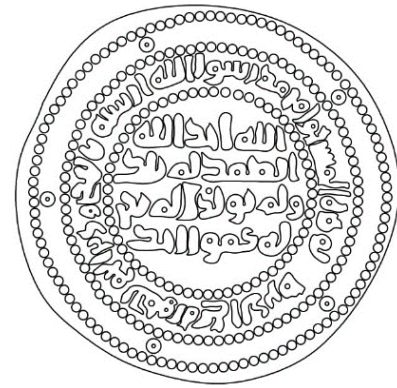

Çizim 5b:

Örnek 3'ün Arka Yüzü

\section{Ön Yüz Okunuşu:}

Ortasinda:

Transkripsiyonu: Lâ ilâhe illa'llah vahdehu lâ şerike leh.

Anlamı: Allah'tan başka ilah yoktur, O birdir ve O'nun ortağı yoktur.

Etrafinda:

Transkripsiyonu: Bismillâh duribe haze'd dirhem Nişabur fî sene ahad semanîn.

Anlamı: Allah'ın adıyla bu dirhem seksen bir senesinde Nişabur'da darp edildi.

\section{Arka Yüz Okunuşu:}

Ortasinda:

الله احد الله الصمد لم يلا ولم يولا ولم يكن له كفوا احد

Transkripsiyon: Allâhu ehad Allâhu's samed lem yelid ve lem yûled. Ve lem yekun lehû kufuven ahad.

Anlamı: Allah tektir. Allah Samed'dir. Ondan çocuk olmamıştır. Kendisi de doğmamıştır. Hiçbir şey O'na denk ve benzer değildir.

Etrafinda:

محمد رسول الله ارسله بالهاى ودين الحق ليظهره على الدين كله ولو كره المشركون Transkripsiyonu: Muhammedü'n Resûlu'llah. Ersele bil hudâ ve dînil hakkı li yuzhirehu aled dîni kullihî ve lev kerihel muşrikûn.

Anlamı: Muhammed Allah'ın elçisidir. O, Allah'a ortak koşanlar hoşlanmasalar bile dinini, bütün dinlere üstün kılmak için, peygamberini hidayetle ve hak dinle gönderendir.

Örnek

Envanter No

Darp Ettiren Hâlife

Darp Tarihi

Darp Yeri

Ölçü Birimi

\section{$: 4$}

: Zeno.ru: \#109397

: I. Velîd b. Abdülmelik

: H.89 - M.707/708

: Bilinmiyor

: 4.24 gr / Dinar

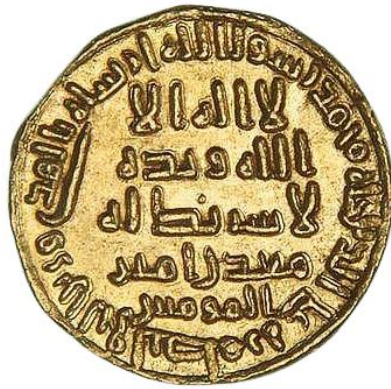

Foto.6a:

Örnek 4’ün Ön Yüzü

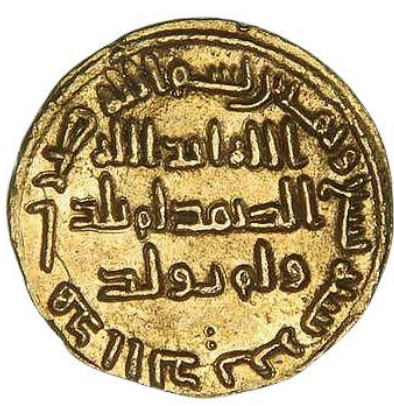

Foto.6b:

Örnek 4'ün Arka Yüzü 


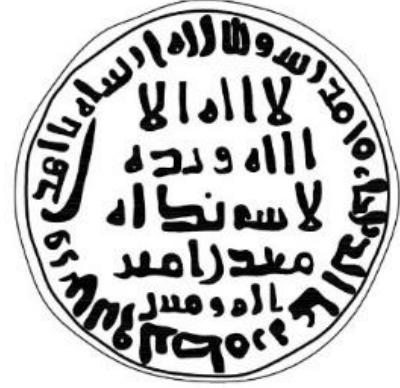

Çizim 6a:

Örnek 4’ün Ön Yüzü

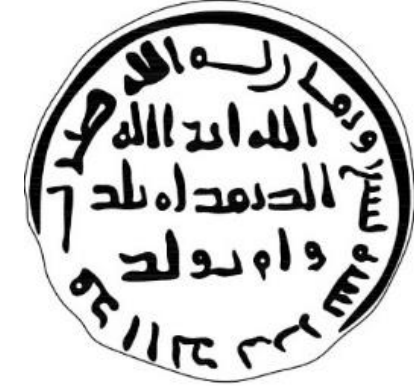

Çizim 6b:

Örnek 4'ün Arka Yüzü

\section{Ön Yüz Okunuşu:}

Ortasinda:

Transkripsiyonu: Lâ ilâhe illa'llah vahdehu lâ şerike leh. Ma'din emîrü'l mü'minîn.

$$
\text { لا اله الا الله وحده لا شريك له / معدن امير المومنين }
$$

Anlamı: Allah'tan başka ilah yoktur, O birdir ve O’nun ortağı yoktur. Müminlerin emirinin madeni.

Etrafinda:

محمد رسول الله ارسله بالهاى ودين الحق ليظهره على الدين كله

Transkripsiyonu: Muhammedü'n Resûlu'llah. Ersele bil hudâ ve dînil hakkı li yuzhirehu aled dîni kullihî.

Anlamı: Muhammed Allah’ın elçisidir. Bütün dinlere üstün kılmak için, peygamberini hidayetle ve hak dinle gönderendir.

\section{Arka Yüz Okunuşu:}

Ortasinda:

الله احد الله الصمد لم يلا ولم يولا

Transkripsiyonu: Allâhu ehad Allâhu's samed lem yelid ve lem yûled.

Anlamı: Allah tektir. Allah Samed'dir. Ondan çocuk olmamıştır. Kendisi de doğmamıştır.

Etrafinda:

بسم الله ضرب هذا الدينر سنة تسع ثمانين

Transkripsiyonu: Bismillâh duribe haze'd dinar sene tis'â semanîn.

Anlamı: Allah'ın adıyla bu dinar seksen dokuz senesinde darp edildi.

Örnek

Envanter No

Darp Ettiren Hâlife

Darp Tarihi

Darp Yeri

Ölçü Birimi

$: 5$

: Zeno.ru: \#109631

: I. Velîd b. Abdülmelik

: H.94 - M.712/713

: Merv

: 2.75 gr / Dirhem

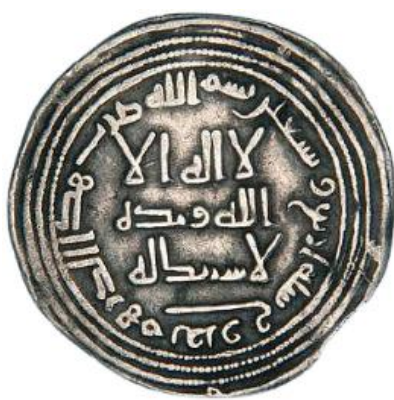

Foto.7a:

Örnek 5 'in Ön Yüzü

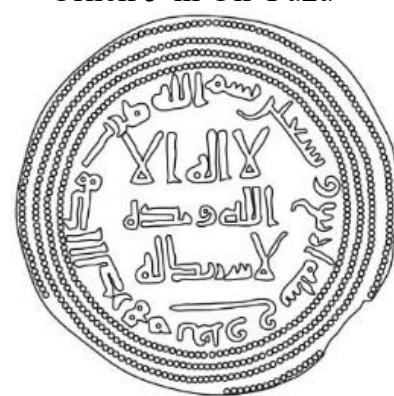

Cizim 7a:

Örnek 5'in Ön Yüzü

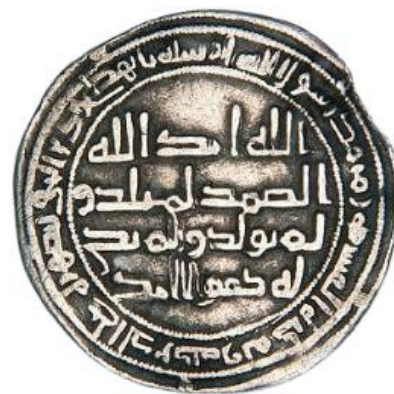

Foto.7b:

Örnek 5'in Arka Yüzü

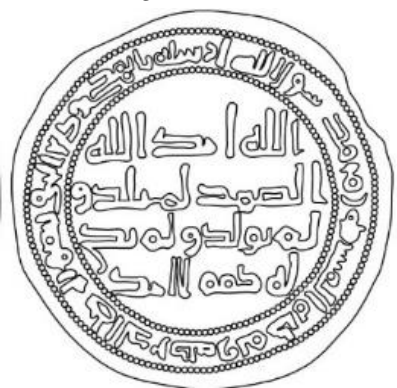

Çizim 7b:

Örnek 5'in Arka Yüzü 


\section{Ön Yüz Okunuşu:}

Ortasinda:

Transkripsiyonu: Lâ ilâhe illa'llah vahdehu lâ şerike leh.

Anlamı: Allah'tan başka ilah yoktur, O birdir ve O'nun ortağı yoktur.

Etrafinda:

Transkripsiyonu: Bismillâh duribe haze'd dirhem bi-Merv fi sene erba'a ve tis'în.

بسم الله ضرب هذا الارهم بمرو في سنة اربع و تسعين

Anlamı: Allah'ın adıyla bu dirhem doksan dört senesinde Merv'de darp edildi.

\section{Arka Yüz Okunuşu:}

Ortasinda:

الله احد الله الصمد لم يلد ولم يولد ولم يكن له كفوا احد

Transkripsiyonu: Allâhu ehad Allâhu's samed lem yelid ve lem yûled. Ve lem yekun lehû kufuven ahad.

Anlamı: Allah tektir. Allah Samed'dir. Ondan çocuk olmamıştır. Kendisi de doğmamıştır. Hiçbir şey O'na denk ve benzer değildir.

\section{Etrafinda:}

محمد رسول الله ارسله بالهُى ودين الحق ليظهره على الدين كله ولو كره المشركون

Transkripsiyonu: Muhammedü’n Resûlu'llah. Ersele bil hudâ ve dînil hakkı li yuzhirehu aled dîni kullihî ve lev kerihel muşrikûn.

Anlamı: Muhammed Allah'ın elçisidir. O, Allah’a ortak koşanlar hoşlanmasalar bile dinini, bütün dinlere üstün kılmak için, peygamberini hidayetle ve hak dinle gönderendir.

Örnek

Envanter No

Darp Ettiren Hâlife

Darp Tarihi

Darp Yeri

Ölçü Birimi
$: 6$

: Zeno.ru: \#214188

: Süleyman b. Abdülmelik

: H.97 - M.715/716

: Bahurasir

: $2.80 \mathrm{gr} /$ Dirhem

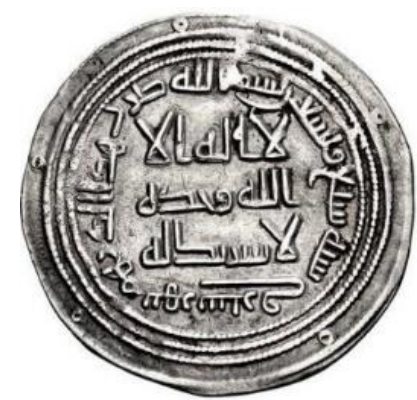

Foto.8a:

Örnek 6'nın Ön Yüzü

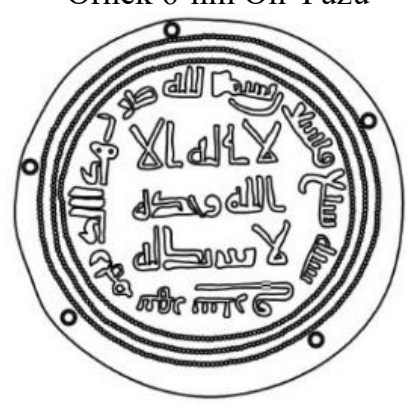

Çizim 8a:

Örnek 6'nın Ön Yüzü

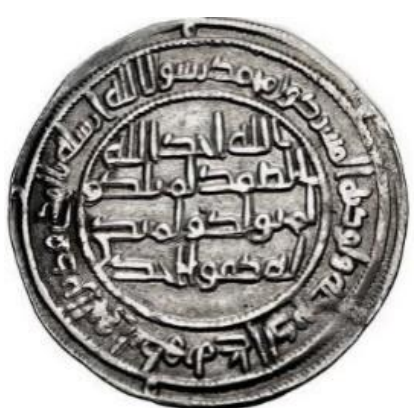

Foto.8b:

Örnek 6'nın Arka Yüzü

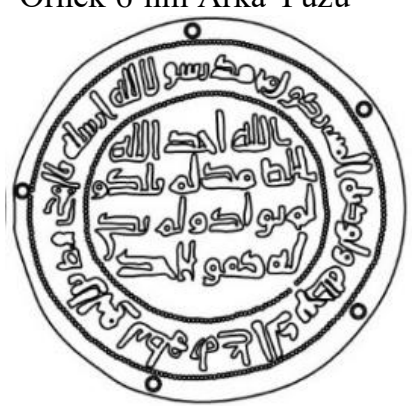

Çizim 8b:

Örnek 6'nın Arka Yüzü

\section{Ön Yüz Okunuşu:}

Ortasinda:

Transkripsiyonu: Lâ ilâhe illa'llah vahdehu lâ şerike leh.

Anlamı: Allah'tan başka ilah yoktur, O birdir ve O'nun ortağı yoktur.

Etrafinda:

Transkripsiyonu: Bismillâh duribe haze'd dirhem bi-Bahuraşir fi sene seb'a tis'în.

Anlamı: Allah'ın adıyla bu dirhem doksan yedi senesinde Bahuraşir'de darp edildi. 


\section{Arka Yüz Okunușu:}

Ortasinda:

الله احد الله الصمد لم يلا ولم يولا ولم يكن له كفوا احد

Transkripsiyonu: Allâhu ehad Allâhu's samed lem yelid ve lem yûled. Ve lem yekun lehû kufuven ahad.

Anlamı: Allah tektir. Allah Samed'dir. Ondan çocuk olmamıştır. Kendisi de doğmamıştır. Hiçbir şey O'na denk ve benzer değildir.

\section{Etrafinda:}

محمد رسول الله ارسله بالهاى ودين الحق ليظهره على الدين كله ولو كره المشركون Transkripsiyonu: Muhammedü'n Resûlu'llah. Ersele bil hudâ ve dînil hakk1 li yuzhirehu aled dîni kullihî ve lev kerihel muşrikûn.

Anlamı: Muhammed Allah’ın elçisidir. O, Allah’a ortak koşanlar hoşlanmasalar bile dinini, bütün dinlere üstün kılmak için, peygamberini hidayetle ve hak dinle gönderendir.

Örnek

Envanter No

Darp Ettiren Hâlife

Darp Tarihi

Darp Yeri

Ölçü Birimi
$: 7$

: Zeno.ru: \#109951

: Ömer b. Abdülazîz

: H.100 - M.718/719

: İfrikiye

: 4.18 gr / Dinar

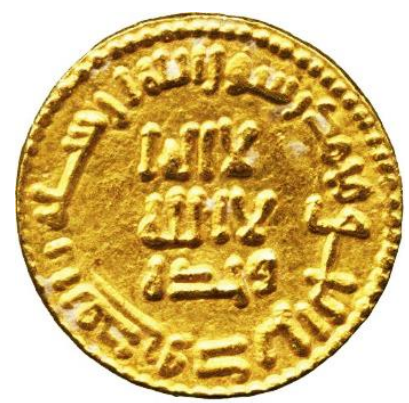

Foto.9a:

Örnek 7'in Ön Yüzü

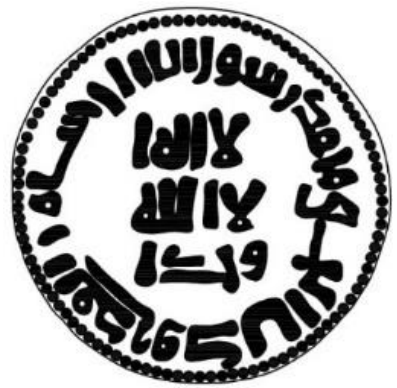

Çizim 9a:

Örnek 7'in Ön Yüzü

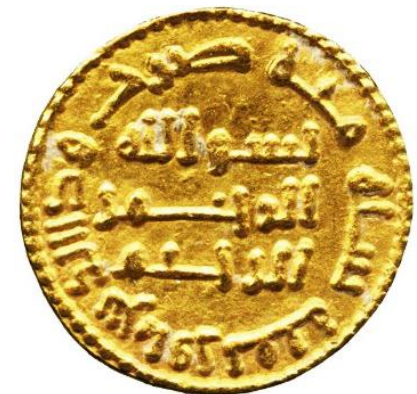

Foto.9b:

Örnek 7'in Arka Yüzü

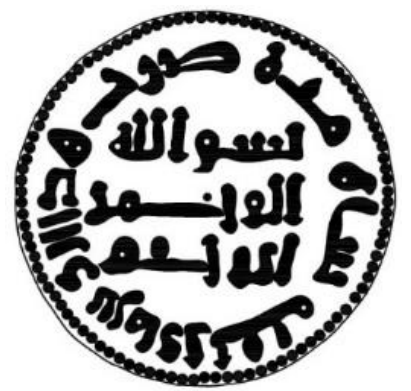

Çizim 9b:

Örnek 7'in Arka Yüzü

\section{Ön Yüz Okunuşu:}

Ortasinda:

Transkripsiyonu: Lâ ilâhe illa'llah vahdehu.

Anlamı: Allah'tan başka ilah yoktur, O birdir.

Etrafinda:

Transkripsiyonu: Muhammedü’n Resûlu'llah. Ersele bil hudâ ve dînil hakk1.

محمد رسول الله ارسله بالهـى ودين الحق

Anlamı: Muhammed Allah'ın elçisidir. Peygamberini hidayetle ve hak dinle gönderendir.

\section{Arka Yüz Okunuşu:}

Ortasinda:

Transkripsiyonu: Bismillâhirrâhmânirrâhîm.

Anlamı: Rahman ve rahim olan Allah'ın adıyla.

Etrafinda:

Transkripsiyonu: Duribe haze'd dinar bi-İfrikiye sene mie.

Anlamı: Bu dinar yüz senesinde İfrikiye'de darp edildi. 

Örnek
Envanter No
Darp Ettiren Hâlife
Darp Tarihi
Darp Yeri
Ölçü Birimi
$: 8$
: Zeno.ru: \#148166
: Ömer b. Abdülazîz
: H.100 - M.718/719
: İfrikiye
: $2.70 \mathrm{gr} /$ Dirhem

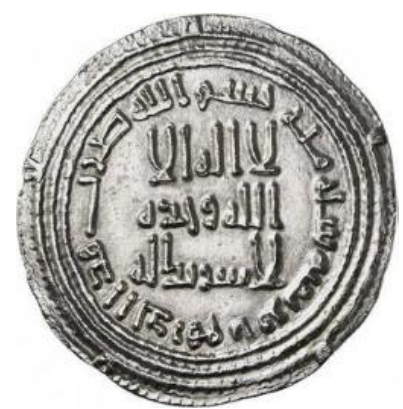

Foto.10a:

Örnek 8'in Ön Yüzü

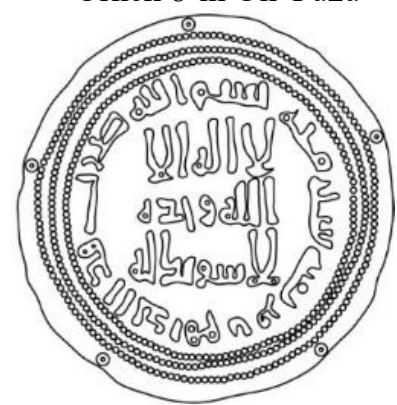

Çizim 10a:

Örnek 8'in Ön Yüzü

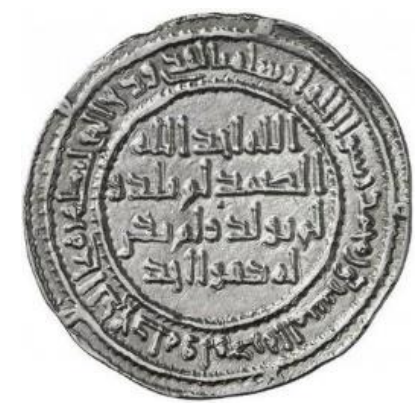

Foto.10b:

Örnek 8'in Arka Yüzü

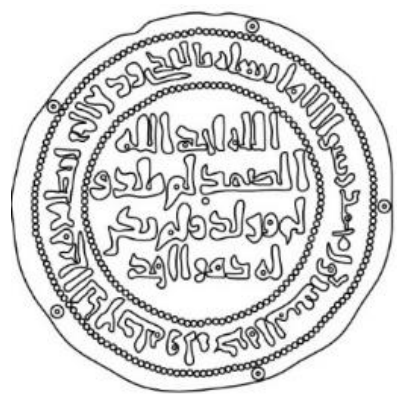

Çizim 10b:

Örnek 8'in Arka Yüzü

\section{Ön Yüz Okunuşu:}

Ortasinda:

Transkripsiyonu: Lâ ilâhe illa'llah vahdehu lâ şerike leh.

Anlamı: Allah'tan başka ilah yoktur, O birdir ve O'nun ortağı yoktur.

Etrafinda:

Transkripsiyonu: Bismillâh duribe haze'd dirhem bi-İfrikiye sene mie.

\section{Arka Yüz Okunuşu:}

Ortasinda:

الله احد الله الصمد لم يلد ولم يولد ولم يكن له كفوا احد

Transkripsiyonu: Allâhu ehad Allâhu's samed lem yelid ve lem yûled. Ve lem yekun lehû kufuven ahad.

Anlamı: Allah tektir. Allah Samed'dir. Ondan çocuk olmamıştır. Kendisi de doğmamıştır. Hiçbir şey O'na denk ve benzer değildir.

\section{Etrafinda:}

محمد رسول الله ارسله بالهاى ودين الحق ليظهره على الدين كله ولو كره المشركون Transkripsiyonu: Muhammedü'n Resûlu'llah. Ersele bil hudâ ve dînil hakkı li yuzhirehu aled dîni kullihî ve lev kerihel muşrikûn.

Anlamı: Muhammed Allah'ın elçisidir. O, Allah'a ortak koşanlar hoşlanmasalar bile dinini, bütün dinlere üstün kılmak için, peygamberini hidayetle ve hak dinle gönderendir.

Örnek

Envanter No

Darp Ettiren Hâlife

Darp Tarihi

Darp Yeri

Ölçü Birimi
$: 9$

: Zeno.ru: \#109967

: II. Yezîd b. Abdülmelik

: H.102 - M.720/721

: El-Endülüs

: $4.30 \mathrm{gr} /$ Dinar 


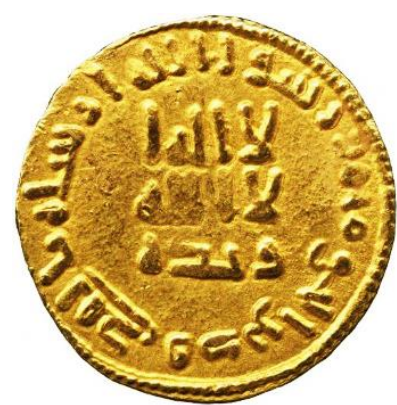

Foto.11a

Örnek 9'un Ön Yüzü

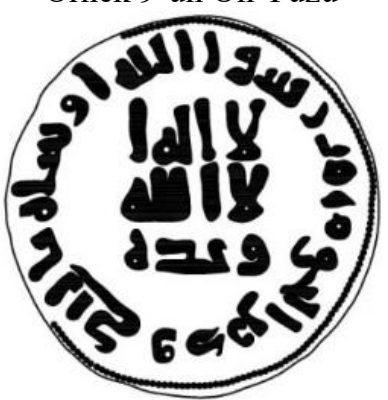

Çizim 11a:

Örnek 9'un Ön Yüzü

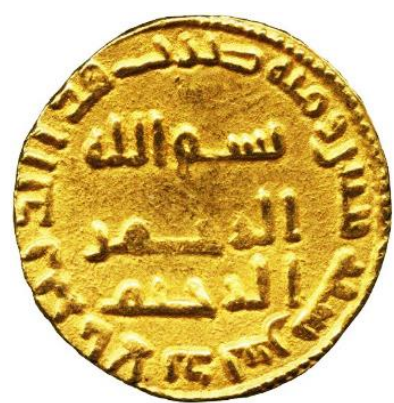

Foto.11b:

Örnek 9'un Arka Yüzü

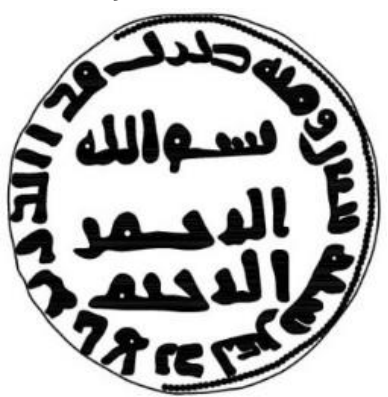

Çizim 11b:

Örnek 9'un Arka Yüzü

\section{Ön Yüz Okunuşu:}

Ortasinda:

Transkripsiyonu: Lâ ilâhe illa'llah vahdehu.

Anlamı: Allah’tan başka ilah yoktur, O birdir.

\section{Etrafinda:}

Transkripsiyonu: Muhammedü'n Resûlu'llah. Ersele bil hudâ ve dînil hakkı.

Anlamı: Muhammed Allah'ın elçisidir. Peygamberini hidayetle ve hak dinle gönderendir.

\section{Arka Yüz Okunuşu:}

Ortasinda:

Transkripsiyonu: Bismillâhirrâhmânirrâhîm.

Anlamı: Rahman ve rahim olan Allah'ın adıyla.

\section{Etrafinda:}

Transkripsiyonu: Duribe haze'd dinar bi-el Endülüs sene isneyn mie.

Anlamı: Bu dinar yüz iki senesinde Endülüs'de darp edildi.

\section{Örnek}

Envanter No

Darp Ettiren Hâlife

Darp Tarihi

Darp Yeri

Ölçü Birimi

$: 10$

\section{: Zeno.ru: \#92668}

: II. Yezîd b. Abdülmelik

: H.102 - M.720/721

: Ermeniye

: $2.79 \mathrm{gr} /$ Dirhem

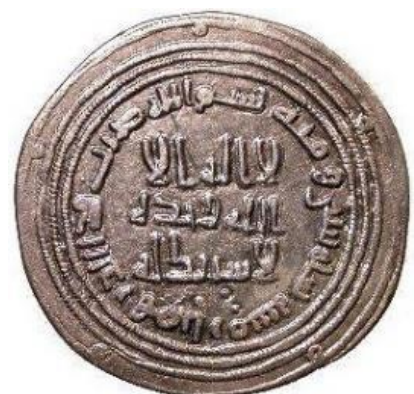

Foto.12a:

Örnek 10’un Ön Yüzü

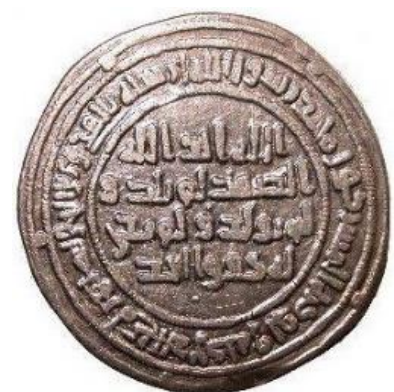

Foto.12b:

Örnek 10’un Arka Yüzü 


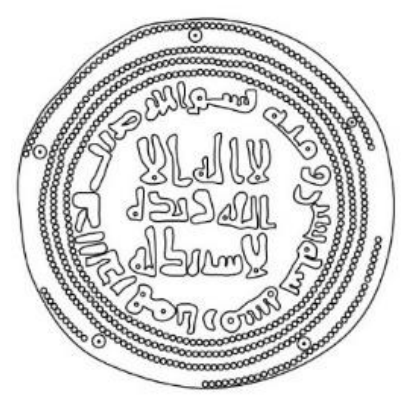

Çizim 12a:

Örnek 10'un Ön Yüzü

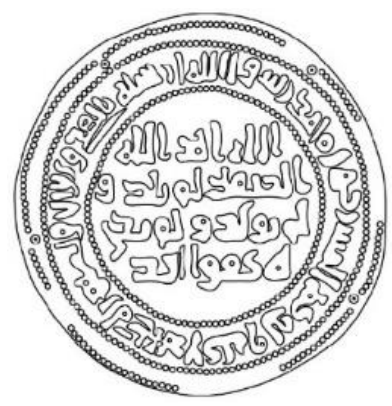

Çizim 12b:

Örnek 10’un Arka Yüzü

\section{Ön Yüz Okunuşu:}

Ortasinda:

Transkripsiyonu: Lâ ilâhe illa'llah vahdehu lâ şerike leh.

Anlamı: Allah'tan başka ilah yoktur, O birdir ve O'nun ortağı yoktur.

\section{Etrafinda:}

Transkripsiyonu: Bismillâh duribe haze'd dirhem bi-Ermeniye sene isneyn mie.

Anlamı: Allah'ın adıyla bu dirhem yüz iki senesinde Ermeniye darp edildi.

\section{Arka Yüz Okunuşu:}

Ortasinda:

الله احد الله الصمد لم يلا ولم يولد ولم يكن له كفوا احد

Transkripsiyonu: Allâhu ehad Allâhu's samed lem yelid ve lem yûled. Ve lem yekun lehû kufuven ahad.

Anlamı: Allah tektir. Allah Samed'dir. Ondan çocuk olmamıştır. Kendisi de doğmamıştır. Hiçbir şey O'na denk ve benzer değildir.

Etrafinda:

محمد رسول الله ارسله بالهُى ودين الدق ليظهره على الدين كله ولو كره المشركون

Transkripsiyonu: Muhammedü'n Resûlu'llah. Ersele bil hudâ ve dînil hakkı li yuzhirehu aled dîni kullihî ve lev kerihel muşrikûn.

Anlamı: Muhammed Allah’ın elçisidir. O, Allah’a ortak koşanlar hoşlanmasalar bile dinini, bütün dinlere üstün kılmak için, peygamberini hidayetle ve hak dinle gönderendir.

Örnek

Envanter No

Darp Ettiren Hâlife

Darp Tarihi

Darp Yeri

Ölçü Birimi

: 11

: Zeno.ru: \#265448

: Hişâm b. Abdülmelik

: H.107 - M.725/726

: Bilinmiyor

: 4.22 gr / Dinar

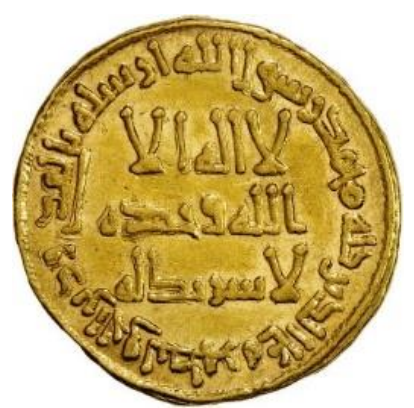

Foto.13a:

Örnek 11'in Ön Yüzü

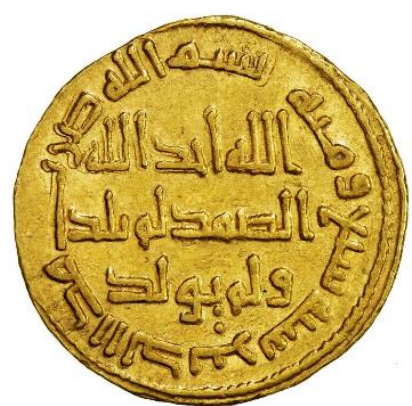

Foto.13b:

Örnek 11'in Arka Yüzü 


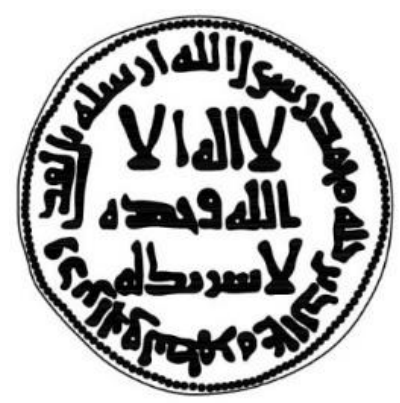

Çizim 13a:

Örnek 11'in Ön Yüzü

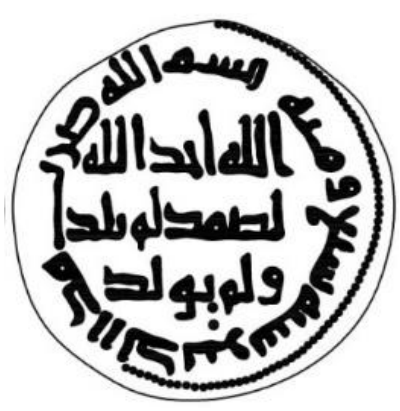

Çizim 13b:

Örnek 11'in Arka Yüzü

\section{Ön Yüz Okunuşu:}

Ortasinda:

Transkripsiyonu: Lâ ilâhe illa'llah vahdehu lâ şerike leh.

Anlamı: Allah'tan başka ilah yoktur, O birdir ve O'nun ortağı yoktur.

Etrafinda:

محمد رسول الله ارسله بالهـى ودين الحق ليظهره على الدين كله Transkripsiyonu: Muhammedü'n Resûlu'llah. Ersele bil hudâ ve dînil hakkı li yuzhirehu aled dîni kullihî.

Anlamı: Muhammed Allah’ın elçisidir. Bütün dinlere üstün kılmak için, peygamberini hidayetle ve hak dinle gönderendir.

\section{Arka Yüz Okunuşu:}

Ortasinda:

الله احد الله الصمد لم يلا ولم يولا

Transkripsiyonu: Allâhu ehad Allâhu's samed lem yelid ve lem yûled.

Anlamı: Allah tektir. Allah Samed'dir. Ondan çocuk olmamıştır. Kendisi de doğmamıştır.

\section{Etrafında:}

Transkripsiyonu: Bismillâh duribe haze'd dinar sene seb'â mie.

Anlamı: Allah'ın adıyla bu dinar yüz yedi senesinde darp edildi.

Örnek

Envanter No

Darp Ettiren Hâlife

Darp Tarihi

Darp Yeri

Ölçü Birimi
$: 12$

: Zeno.ru: \#226189

: Hişâm b. Abdülmelik

: H.109 - M.725/726

: El-Endülüs

: 4.28 gr / Dinar

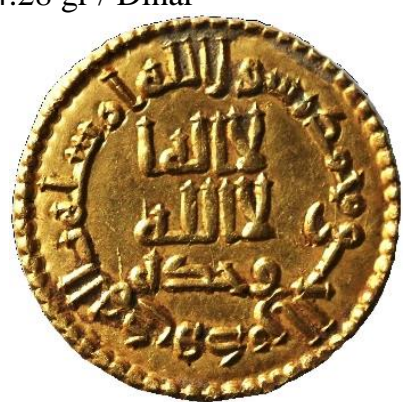

Foto.14a:

Örnek 12'nin Ön Yüzü

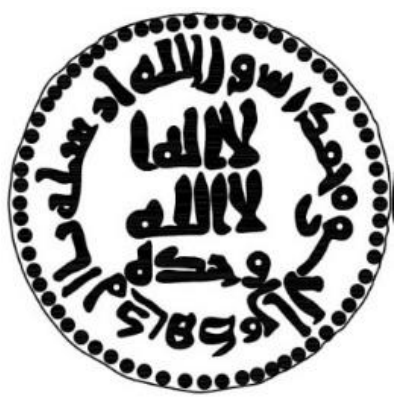

Çizim 14a:

Örnek 12'nin Ön Yüzü

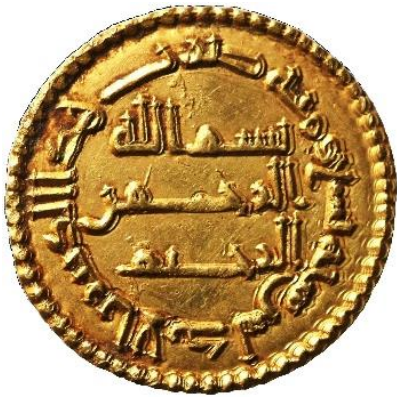

Foto.14b:

Örnek 12'nin Arka Yüzü

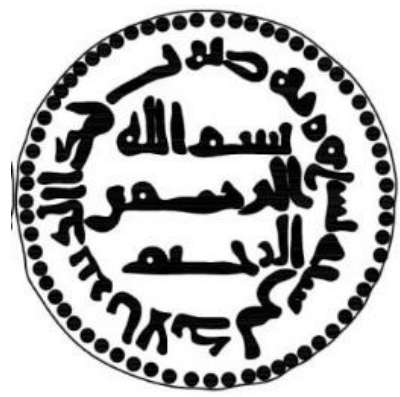

Çizim 14b:

Örnek 12'nin Arka Yüzü 


\section{Ön Yüz Okunuşu:}

Ortasinda:

Transkripsiyonu: Lâ ilâhe illa'llah vahdehu.

Anlamı: Allah'tan başka ilah yoktur, O birdir.

Etrafinda:

Transkripsiyonu: Muhammedü'n Resûlu'llah. Ersele bil hudâ ve dînil hakk1.

Anlamı: Muhammed Allah'ın elçisidir. Peygamberini hidayetle ve hak dinle gönderendir.

\section{Arka Yüz Okunușu:}

Ortasinda:

Transkripsiyon: Bismillâhirrâhmânirrâhîm.

Anlamı: Rahman ve rahim olan Allah'ın adıyla.

Etrafinda:

Transkripsiyon: Duribe haze'd dinar bi-el Endülüs sene tis'â mie.

Anlamı: Bu dinar yüz dokuz senesinde Endülüs'de darp edildi.

Örnek

Envanter No

Darp Ettiren Hâlife

Darp Tarihi

Darp Yeri

Ölçü Birimi
$: 13$

: Zeno.ru: \#250681

: Hişâm b. Abdülmelik

: H.111 - M.729/730

: El Endülüs

: $2.57 \mathrm{gr} /$ Dirhem

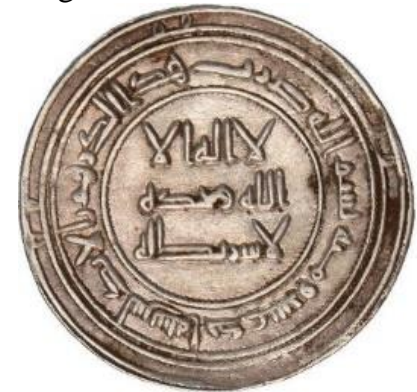

Foto.15a:

Örnek 13'ün Ön Yüzü

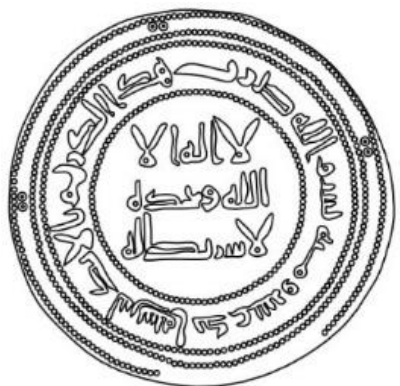

Çizim 15a:

Örnek 13'ün Ön Yüzü

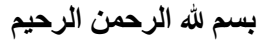

ضرب هذا الدينر بالاندلس سنة تسع مانة

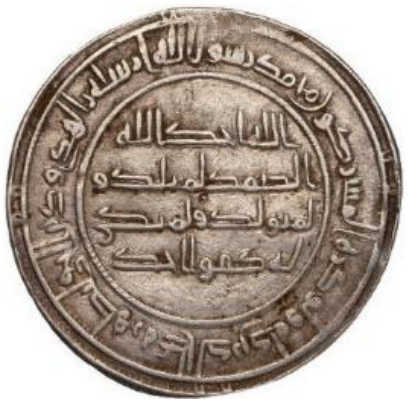

Foto.15b:

Örnek 13'ün Arka Yüzü

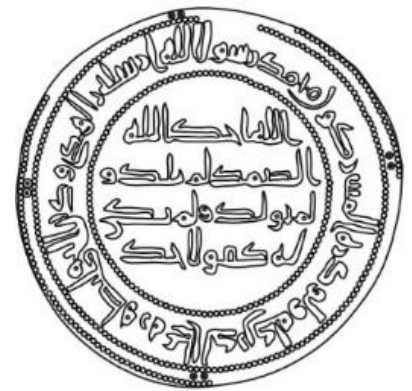

Çizim 15b:

Örnek 13'ün Arka Yüzü

\section{Ön Yüz Okunuşu:}

Ortasinda:

Transkripsiyonu: Lâ ilâhe illa'llah vahdehu lâ şerike leh.

Anlamı: Allah'tan başka ilah yoktur, O birdir ve O'nun ortağı yoktur.

Etrafinda:

بسم الله ضرب هذا الدرهم بالاندلس سنة احاد عشر مانة

Transkripsiyonu: Bismillâh duribe haze'd dirhem bi-Endülüs sene ehad aşer mie.

Anlamı: Allah'ın adıyla bu dirhem yüz on bir senesinde el Endülüs'te darp edildi.

\section{Arka Yüz Okunuşu:}

Ortasinda:

Transkripsiyonu: Allâhu ehad Allâhu's samed lem yelid ve lem yûled. Ve lem yekun lehû kufuven ahad. 
Anlamı: Allah tektir. Allah Samed'dir. Ondan çocuk olmamıştır. Kendisi de doğmamıştır. Hiçbir şey O'na denk ve benzer değildir.

\section{Etrafinda:}

Transkripsiyonu: Muhammedü'n Resûlu'llah. Ersele bil hudâ ve dînil hakkı li yuzhirehu aled dîni kullihî ve lev kerihel muşrikûn.

Anlamı: Muhammed Allah'ın elçisidir. O, Allah'a ortak koşanlar hoşlanmasalar bile dinini, bütün dinlere üstün kılmak için, peygamberini hidayetle ve hak dinle gönderendir.

$\begin{array}{ll}\text { Örnek } & : 14 \\ \text { Envanter No } & : \text { Zeno.ru: \#165920 } \\ \text { Darp Ettiren Hâlife } & : \text { Hişâm b. Abdülmelik } \\ \text { Darp Tarihi } & : \text { H.120 - M.729/730 } \\ \text { Darp Yeri } & : \text { Vasit } \\ \text { Ölçü Birimi } & : 2.97 \text { gr / Dirhem }\end{array}$

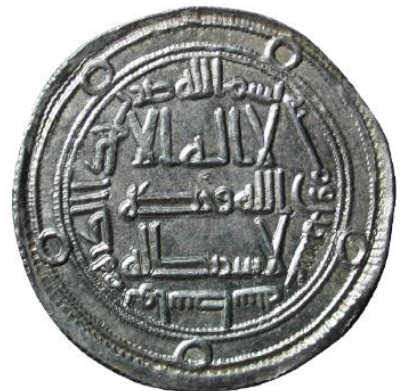

Foto.16a:

Örnek 14’ün Ön Yüzü

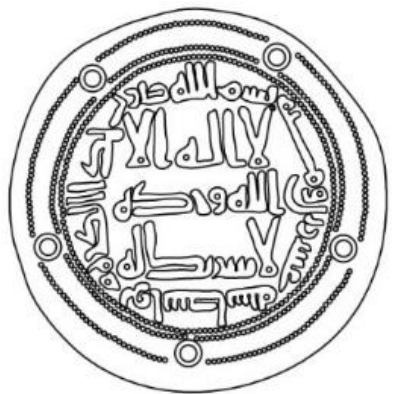

Çizim 16a:

Örnek 14'ün Ön Yüzü

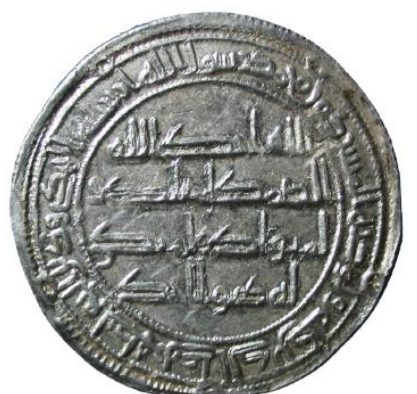

Foto.16b:

Örnek 14'ün Arka Yüzü

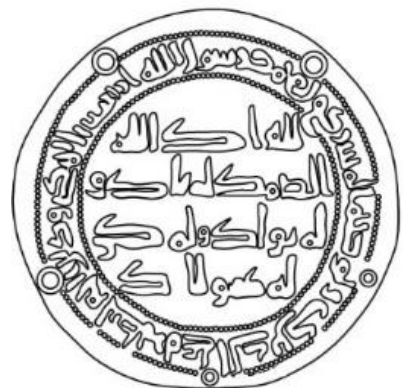

Çizim 16b:

Örnek 14’ün Arka Yüzü

\section{Ön Yüz Okunuşu:}

Ortasinda:

Transkripsiyonu: Lâ ilâhe illa'llah vahdehu lâ şerike leh.

Anlamı: Allah'tan başka ilah yoktur, O birdir ve O'nun ortağı yoktur.

Etrafinda:

Transkripsiyon: Bismillâh duribe haze'd dirhem bi-Vasit sene işrûn mie.

بسم الله ضرب هذا الارهم باواسيط سنة عشرين مانة

Anlamı: Allah'ın adıyla bu dirhem yüz yirmi senesinde Vasit'de darp edildi.

\section{Arka Yüz Okunuşu:}

Ortasinda:

الله احد الله الصمد لم يلا ولم يولا ولم يكن لله كفوا احد

Transkripsiyonu: Allâhu ehad Allâhu's samed şem yelid ve lem yûled. Ve lem yekun lehû kufuven ahad.

Anlamı: Allah tektir. Allah Samed'dir. Ondan çocuk olmamıştır. Kendisi de doğmamıştır. Hiçbir şey O'na denk ve benzer değildir.

\section{Etrafinda:}

محمد رسول الله ارسله بالهُى ودين الحق ليظهره على الدين كله ولو كره المشركون Transkripsiyonu: Muhammedü’n Resûlu'llah. Ersele bil hudâ ve dînil hakkı li yuzhirehu aled dîni kullihî ve lev kerihel muşrikûn.

Anlamı: Muhammed Allah'ın elçisidir. O, Allah'a ortak koşanlar hoşlanmasalar bile dinini, bütün dinlere üstün kılmak için, peygamberini hidayetle ve hak dinle gönderendir. 
Örnek

Envanter No

Darp Ettiren Hâlife

Darp Tarihi

Darp Yeri

Ölçü Birimi
$: 15$

: Zeno.ru: \#200637

: İbrâhim b. I. Velîd

: H.127 - M.744/745

: Bilinmiyor

: 4.27 gr / Dinar

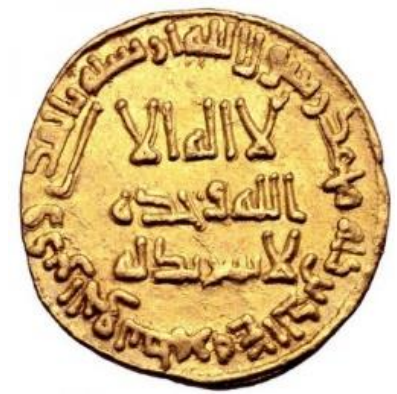

Foto.17a:

Örnek 15'in Ön Yüzü

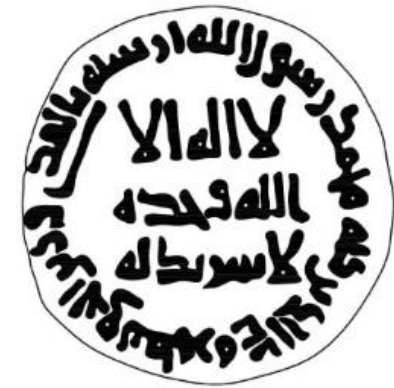

Çizim 17a:

Örnek 15'in Ön Yüzü

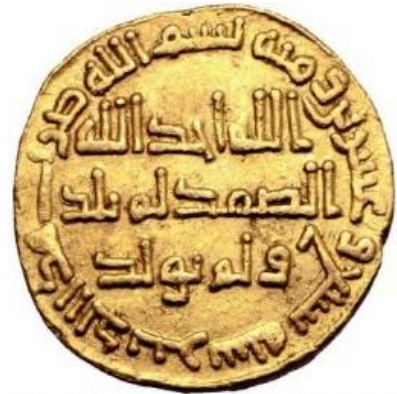

Foto.17b:

Örnek 15'in Arka Yüzü

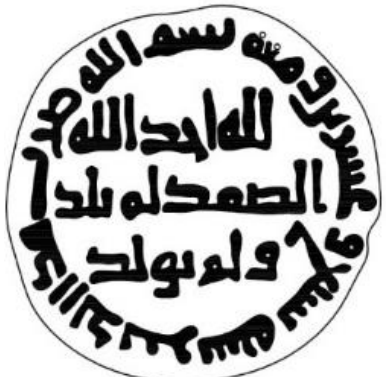

Çizim 17b:

Örnek 15'in Arka Yüzü

\section{Ön Yüz Okunuşu:}

Ortasinda:

Transkripsiyonu: Lâ ilâhe illa'llah vahdehu lâ şerike leh.

Anlamı: Allah'tan başka ilah yoktur, O birdir ve O'nun ortağı yoktur.

Etrafinda:

محمد رسول الله ارسله بالهـى ودين الحق ليظهره على الدين كله

Transkripsiyonu: Muhammedü'n Resûlu'llah. Ersele bil hudâ ve dînil hakkı li yuzhirehu aled dîni kullihî.

Anlamı: Muhammed Allah'ın elçisidir. Bütün dinlere üstün kılmak için, peygamberini hidayetle ve hak dinle gönderendir.

\section{Arka Yüz Okunuşu:}

Ortasinda:

Transkripsiyonu: Allâhu ehad Allâhu's samed lem yelid ve lem yûled.

Anlamı: Allah tektir. Allah Samed'dir. Ondan çocuk olmamıştır. Kendisi de doğmamıştır.

\section{Etrafinda:}

Transkripsiyonu: Bismillâh duribe haze'd dinar sene seb'â işrûn mie.

Anlamı: Allah'ın adıyla bu dinar yüz yirmi yedi senesinde darp edildi.

Örnek

Envanter No

Darp Ettiren Hâlife

Darp Tarihi

Darp Yeri

Ölçü Birimi
: 16

: Zeno.ru: \#76016

: II. Mervân b. Muhammed.

: H.128 - M.745/746

: El-Bab

: $2.87 \mathrm{gr} /$ Dirhem 


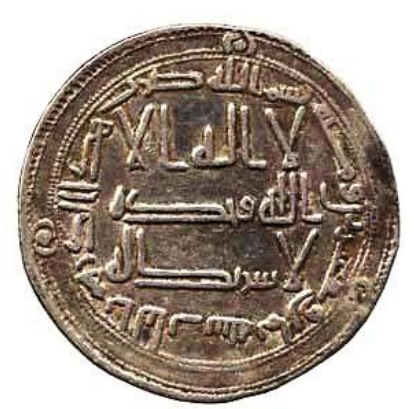

Foto.18a:

Örnek 16'1n Ön Yüzü

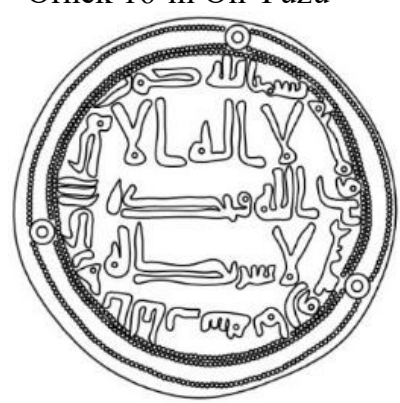

Çizim 18a:

Örnek 16'ın Ön Yüzü

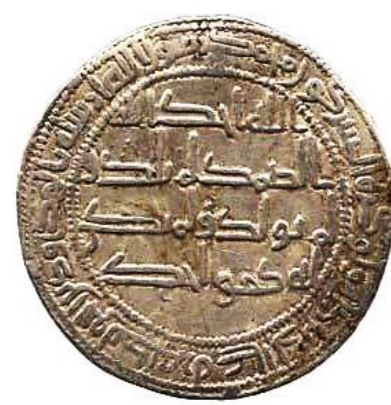

Foto.18b:

Örnek 16'ın Arka Yüzü

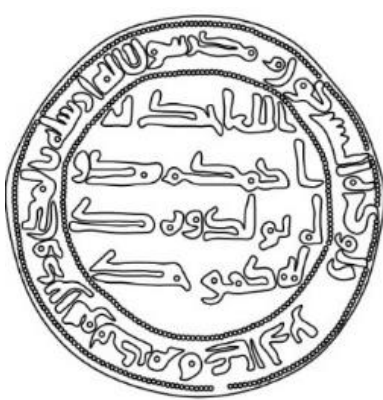

Çizim 18b:

Örnek 16'ın Arka Yüzü

\section{Ön Yüz Okunuşu:}

Ortasinda:

Transkripsiyonu: Lâ ilâhe illa'llah vahdehu lâ şerike leh.

Anlamı: Allah'tan başka ilah yoktur, O birdir ve O'nun ortağı yoktur.

\section{Etrafinda:}

بسم لله ضرب هذا الار هم بالباب سنة ثمان عشرين مانة

Transkripsiyonu: Bismillâh duribe haze'd dirhem bi-el Bab sene seman işrûn mie.

Anlamı: Allah'ın adıyla bu dirhem yüz yirmi sekiz senesinde el Bab'da darp edildi.

\section{Arka Yüz Okunuşu:}

Ortasinda:

الله احد الله الصمد لم يلد ولم يولد ولم يكن له كفوا احد

Transkripsiyonu: Allâhu ehad Allâhu's samed Lem yelid ve lem yûled. Ve lem yekun lehû kufuven ahad

Anlamı: Allah tektir. Allah Samed'dir. Ondan çocuk olmamıştır. Kendisi de doğmamıştır. Hiçbir şey O'na denk ve benzer değildir.

Etrafinda:

محمد رسول الله ارسله بالهاى ودين الحق ليظهره على الادين كله ولو كره المشركون

Transkripsiyonu: Muhammedü'n Resûlu'llah. Ersele bil hudâ ve dînil hakkı li yuzhirehu aled dîni kullihî ve lev kerihel muşrikûn.

Anlamı: Muhammed Allah'ın elçisidir. O, Allah'a ortak koşanlar hoşlanmasalar bile dinini, bütün dinlere üstün kılmak için, peygamberini hidayetle ve hak dinle gönderendir.

Örnek

Envanter No

Darp Ettiren Hâlife

Darp Tarihi

Darp Yeri

Ölçü Birimi
$: 17$

: Zeno.ru: \#161249

: II. Mervân b. Muhammed.

: H.132 - M.749/750

: Bilinmiyor

: 4.27 gr / Dinar 


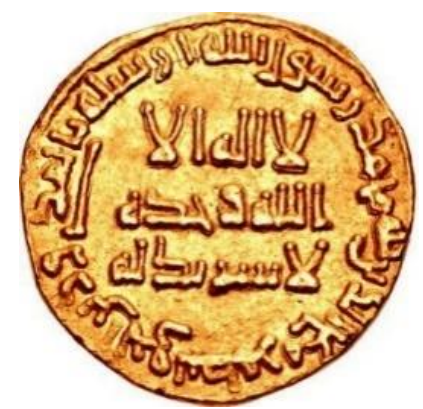

Foto.19a:

Örnek 17'nin Ön Yüzü

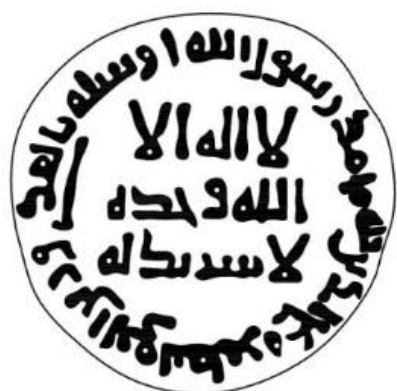

Çizim 19a:

Örnek 17'nin Ön Yüzü

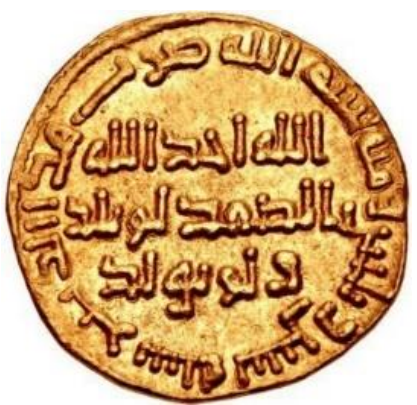

Foto: 19b:

Örnek 17'nin Arka Yüzü

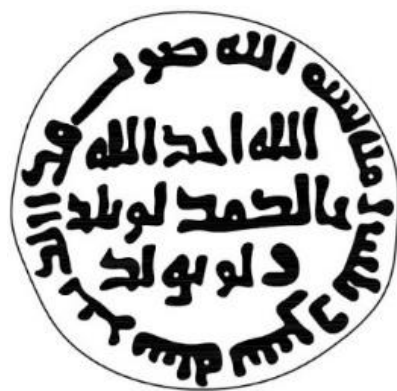

Çizim 19b:

Örnek 17'nin Arka Yüzü

\section{Ön Yüz Okunuşu:}

Ortasinda:

Transkripsiyonu: Lâ ilâhe illa'llah vahdehu lâ şerike leh.

Anlamı: Allah'tan başka ilah yoktur, O birdir ve O'nun ortağı yoktur.

\section{Etrafinda:}

محمد رسول الله ارسله بالهُى ودين الحق ليظهره على الدين كله Transkripsiyonu: Muhammedü’n Resûlu'llah. Ersele bil hudâ ve dînil hakkı li yuzhirehu aled dîni kullihî.

Anlamı: Muhammed Allah'ın elçisidir. Bütün dinlere üstün kılmak için, peygamberini hidayetle ve hak dinle gönderendir.

\section{Arka Yüz Okunuşu:}

Ortasinda:

Transkripsiyonu: Allâhu ehad Allâhu's samed lem yelid ve lem yûled.

Anlamı: Allah tektir. Allah Samed'dir. Ondan çocuk olmamıştır. Kendisi de doğmamıştır.

\section{Etrafinda:}

Transkripsiyonu: Bismillâh duribe haze'd dinar sene isneyn selasîn mie.

Anlamı: Allah'ın adıyla bu dinar yüz otuz iki senesinde darp edildi.

\section{Örnek}

Envanter No

Darp Ettiren Hâlife

Darp Tarihi

Darp Yeri

Ölçü Birimi

$: 18$

: Zeno.ru: \#222232

: II. Mervân b. Muhammed.

: H.132 - M.749/750

: Dimeşk

: 2.86 gr / Dirhem

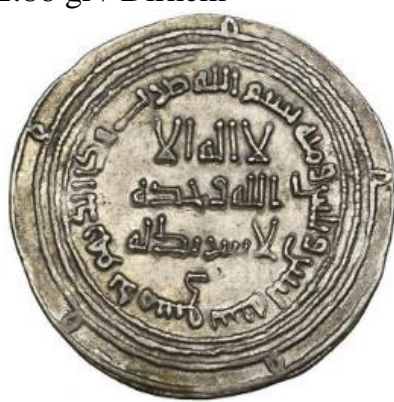

Foto.20a:

Örnek 18'nin Ön Yüzü

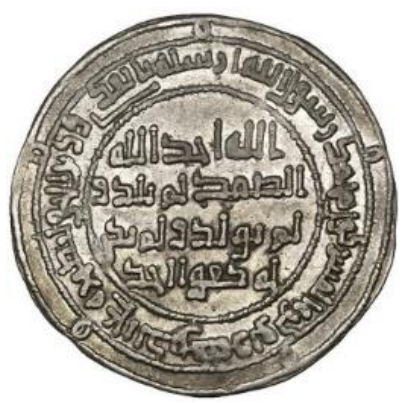

Foto.20b:

Örnek 18'nin Arka Yüzü 

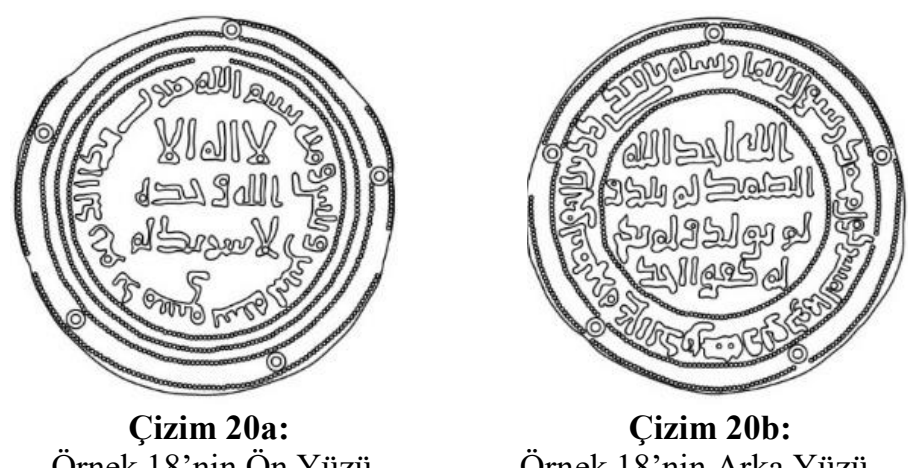

\section{Ön Yüz Okunuşu:}

Ortasinda:

Örnek 18'nin Arka Yüzü

Transkripsiyonu: Lâ ilâhe illa'llah vahdehu lâ şerike leh.

Anlamı: Allah'tan başka ilah yoktur, O birdir ve O'nun ortağı yoktur.

Etrafinda:

Transkripsiyonu: Bismillâh duribe haze'd dirhem bi-Dimeşk sene isneyn selasîn mie.

Anlamı: Allah'ın adıyla bu dirhem yüz otuz iki senesinde Dimeşk'de darp edildi.

\section{Arka Yüz Okunuşu:}

Ortasinda:

الله احد الله الصمد لم يلا ولم يولا ولم يكن لله كفوا احد

Transkripsiyonu: Allâhu ehad Allâhu's samed lem yelid ve lem yûled. Ve lem yekun lehû kufuven ahad.

Anlamı: Allah tektir. Allah Samed'dir. Ondan çocuk olmamıştır. Kendisi de doğmamıştır. Hiçbir şey O'na denk ve benzer değildir.

Etrafinda:

محمد رسول الله ارسله بالهـى ودين الحق ليظهره على الدين كله ولو كره المشركون Transkripsiyonu: Muhammedü'n Resûlu'llah. Ersele bil hudâ ve dînil hakkı li yuzhirehu aled dîni kullihî ve lev kerihel muşrikûn.

Anlamı: Muhammed Allah'ın elçisidir. O, Allah'a ortak koşanlar hoşlanmasalar bile dinini, bütün dinlere üstün kılmak için, peygamberini hidayetle ve hak dinle gönderendir.

\section{SONUÇ}

İslam'ın yayıldığı ilk dönemlerde İslami tarzda sikkenin darp edilmesine yönelik herhangi bir çalışma gerçekleştirilmemiştir. Bu dönemde, Bizans dinarları ve İran dirhemleri kullanılmaya devam edilmiştir. İslami karakterde ilk sikke darbı; siyasi ve ekonomik sorunların ortadan kaldırılması için yapılan reform sonrasında Abdülmelik b. Mervân tarafından gerçekleştirilmiştir. Emevîler, Abdülmelik b. Mervân tarafından 697 yılında gerçekleştirilen sikke reformu sonucunda İslami süsleme anlayışına uygun olarak sikkeler üzerinde benzer düzenlemelerle altın ve gümüş sikkeler darp ettirmiştir. Bu sikkelerin malzemesi, tekniği ve üzerinde yer alan düzenlemeleri değerlendirildiğinde Emevîlerin ekonomik durumu, siyasi yapısı, yönetim biçimi ve sanatsal üslubu hakkında önemli bilgilere ulaşılmaktadır.

Çalışma kapsamında ele alınan bu sikke örneklerinin; 3'ü Abdülmelik b. Mervân (H.65-86/M.685-M.705); 2'si I. Velîd b. Abdülmelik (H.86-96/M.705-715); 1'i Süleyman b. Abdülmelik (H.96-99/M.715-717); 2'si Ömer b. Abdülazîz (H.99101/M.717-720); 2'si II. Yezîd b. Abdülmelik (H.101-105/M.720-724); 4'ü Hişâm b. Abdülmelik (H.105-125/M.724-743); 1'i İbrâhim b. I. Velîd (H.126/M.744); 3’ü II. Mervân b. Muhammed (H.127-132/M.744-750) tarafindan darp edilmiştir.

Sikkelerin 10 tanesi gümüş, 8 tanesi altındır. Gümüşs sikkeler; dirhem, altın sikkeler; dinar olarak adlandırılmaktadır. Çekiç ile darp tekniğinde darp edilen sikkelerin ağırlık ölçüleri dirhemlerde; 2.57 gr ile 2.97 gr, dinarlarda; 4.18 gr ile 4.30 gr arasındadır.

Sikkelerin üzerinde yer alan süsleme unsurları; yazı ve geometrik şekillerdir. Bu düzenlemeler, sikke örneklerinin tamamında bulunmaktadır.

Yazılar, sikkeler üzerinde satırlar halinde ya da dairesel yazı kuşağı şeklinde konumlandırılmıştır. Bu yazılar, Arap alfabesi ile kufî yazı karakterinde yazılmıştır. Yazıların içerikleri; sikkenin darp yeri, darp tarihi, sikkeyi darp ettiren hâlifenin unvanı ile dini ibarelerden teşekküldür.

İncelenen sikkeler; Ermeniye, Nişabur, Merv, Bahurasir, İfrikiye, Vasit, El-Bab, Dimeşk gibi Emevîlerin hâkimiyet sağladığı şehirlerde darp edilmiştir. Bazı sikkelerin ise darp yerlerinin yazılmadığı tespit edilmiştir. Darp yılı, sikkelerin tamamında hicri takvime göre yazılmıştır. İncelenen sikkeler, 78-132 yılları arasına tarihlenmektedir. Çalışmada yer alan sikkelerin üzerinde darp yılı ve darp yerinin yazılması sikkelerin tarihlendirilmesi açısından önemli bir yere sahiptir. İncelenen sikkelerin üzerinde sikkeyi darp ettiren hâlifeye ait bilgiler yazılmamıştır. $\mathrm{Bu}$ nedenle anonim sikke görünümündeki bu 
sikkelerde darp yeri ve darp tarihi karşılaştırılarak sikkeyi darp ettiren hâlife belirlenebilmiştir. Sikkelerin tamamında Besmele, Kelime-i Tevhid ve Kuran-Kerim'den ayetler gibi dini ibareli yazılar işlenmiştir. Bu ibareler: "Bismillâh", "Bismillâhirrâhmânirrâhîm", "Lâ ilâhe illa'llah vahdehu lâ şerike leh", "Lâ ilâhe illa'llah vahdehu", "Muhammedü'n Resûlu'llah. Ersele bil hudâ ve dînil hakkı li yuzhirehu aled dîni kullihî ve lev kerihel muşrikûn", "Muhammedü'n Resûlu'llah. Ersele bil hudâ ve dînil hakkı li yuzhirehu aled dîni kullihî", "Muhammedü’n Resûlu'llah. Ersele bil hudâ ve dînil hakk1", “Allâhu ehad Allâhu's-samed lem yelid ve lem yûled. Ve lem yekun lehû kufuven ahad”, “Allâhu ehad Allâhu's samed lem yelid ve lem yûled” şeklindedir. Sikkelerde tespit edilen tek hâlife unvanı "Emîrü’l mü'minîn” dir.

Teokratik devlet yönetimine sahip olan Emevîlerin, darp ettirdiği bu sikkeleri ödeme aracı olarak kullanmasının yanı sıra bilinçli bir şekilde propaganda amacıyla da kullanıldığı düşünülmektedir. Halîfelerin istikrarlı olarak sikkelerin ön ve arka yüzlerine işledikleri Kuran'ı Kerim'den ayetler ile İslâm dinine tebliği ve İslâm'ın temel esaslarından biri olan Tevhid inancını, ticari faaliyetlerle geniş bir coğrafi alana dağılan sikkelerin aracılığıyla duyurmaya çalıştığı anlaşılmaktadır.

Çalışmada yer alan dînâr ve dirhemlerin üzerinde figüratif ve bitkisel süsleme ile karşılaşılmamıştır. Sikkeler üzerindeki ana süsleme unsuru geometrik formlardır. Bunun nedeni Abdülmelik b. Mervan'ın sikke reformunun dördüncü evresinde Bizans İmparatorları gibi ayakta kendini tasvir ettiği sikkelerin İslâm âlimleri ve müminler tarafından hoş görülmemesi olarak açıklanabilir.

Sikkelerdeki geometrik şekiller sonsuzluk anlayışı içerisinde simetrik olarak yerleştirilmiş kontur uygulamalıdır. Kontur uygulamalarını düz hatlı ve inci dizili daireler oluşturmaktadır. Dairesel konturlar sikke yüzeyinde genellikle ana motif olarak yer almaktadır. Dairesel konturlar bu uygulamanın dışında, ana konturların boş alanlarını hareketlendiren süsleme unsuru olarak kullanılmıştır.

Bu yönleriyle Abdülmelik b. Mervan ve haleflerinin darp ettirdiği sikkeler, ilk İslâmî sikke geleneğini oluşturmuştur. İslâm dünyasının kuvvetini ve bağımsızlığını simgeleyen bu sikkeler Emevîler sonrasında İslam devletleri tarafından darp edilen sikkelere model olmuştur.

\section{KAYNAKÇA}

Artuk, İ., \& Artuk, C. (1971). İstanbul Arkeoloji Müzeleri Teşhirdeki İslâmî Sikkeler Kataloğu (Cilt I). İstanbul: Millî Eğitim Basımevi.

Aydoğdu, G. (2018). Reform Öncesi ve Sonrasında Emevi Dönemi Altın ve Gümüş Sikkeleri. History Studies, 6, 1-12.

Aydoğdu, G. (2018). Tarihi Olaylar Bağlamında Abâsîler Dönemi Altın ve Gümüş Sikkeleri. Stratejik ve Sosyal Araştırmalar Dergisi, 2 (1), 55-69.

Aykut, T. (1982). Emevi Sikkeleri. İstanbul: Yapı Kredi Bankası A.Ş - Numismatik Yayınları.

Bacharach, J. L. (2004). Misır ve Suriye İslami Sikkelerini “Okumak” (Osmanlı Dönemine Kadar). Altının İktidarl, İktidarın Altınlarl, İstanbul: Yapı Kredi Yayınları, 69-77.

Bal, F. (2014). Çölün Ekonomisi: İslam Öncesi Arap Yarımadası'nda Ticaret, Ortaklık, Para ve Kredi. Akademik Ortadoğu, 9 (1), 95-1188.

Damalı, A. (2001). 150 Devlet 1500 Sultan: İslam Sikkeleri. İstanbul: Nilifer Vakfi Yayınları.

Demirel Gökalp, Z. (2009). Yalvaç Müzesi Bizans Sikkeleri. Ankara: Kültür Varlıkları ve Müzeler Genel Müdürlüğü Yayınları.

Dursun Yıldız, H. (1988). Abülmelik b. Mervân. Türkiye Diyanet Vakfı İslâm Ansiklopedisi, C. 1, İstanbul: TDV. Yayınları, 266-170.

Emanet, C. (2014). Emeviler Döneminde Para. Düşünce - Yorum Sosyal Bilimler Araştırması Dergisi, 7 (13), $251-1269$.

Erdoğan, N. (2015). Doğu Roma Sikkeleri (M.S. 491 - 1453). Mardin: Mardin Müzesi Müdürlüğü.

Erkoçoğlu, F. (2007). Abdülmelik B. Mervân'ın Para Reformu. İslâm, Sanati Tarih, Edebiyat ve Musikisi Dergisi, (8), $171-186$.

Günay, E. (2019). Mardin Müzesi'ndeki Eyyûbî Sikkeleri. İstanbul: Hiper Yayınları.

Kalkan. M. (2019). İslam Medeniyet Dairesi İçerisinde Sikkeler. Kullanımları ve Gelişim Seyirleri, 9 (Özel), 83-112.

Karakoç, İ. (2021). Osmalı Devleti'nde Kâğıt Paraya Geçiş Sürecinde Evrâk-ı Nakdiyyenin Yeri. Yıldırım Beyazıt Hukuk Dergisi, $1,1-54$.

Karwiese, S. (2004). Antik Nümizmatiğe Giriş. İstanbul: Arkeloji ve Sanat Yayınları.

Pamuk, Ş. (2000). Osmanlı Imparatorluğu’nda Paranın Tarihi. İstanbul: Tarih Vakfı Yurt Yayınları.

Sahillioğlu, H. (1993). Darphâne. Türk Diyanet Vakfi İslam Anskilopedisi, C. 8, İstanbul: TDV. Yayınları, 501-505. 
Sivrioğlu, U. (2014). Ortaçağ İslam Sikkelerinde Hellen, Roma-Bizans Etkisi. Akademik Tarih ve Düşünce Dergisi, $1,50-71$.

Şimşir, M. (2017). Cahiliye Dönemi Araplarında Para ve İlk İslâm Paralarının Tedavüle Giriş Süreci. Uluslararası Tarih ve Araştırmalar Dergisi, 18, 117-136.

Tekin, O. (2009). Sikke. Türk Diyanet Vakfi İslam Anskilopedisi, C. 37, İstanbul: TDV. Yayınları, 179-184.

Uslu, R. (2014). İslâm Hukunda Para Birimleri. İslâmi Araştırmalar Dergisi, (1), 28-38.

Yiğit, İ. (1995). Emevîler. Türk Diyanet Vakfı İslam Anskilopedisi, C. 11, İstanbul: TDV. Yayınları, 87-104.

$\begin{array}{lllll}\text { www.coinarchives.com. } & 05 & 02, & 2021 & \text { tarihinde }\end{array}$ https://www.coinarchives.com/w/lotviewer.php?LotID=5078321\&AucID=5711\&Lot=4251\&Val=14b191faa9ae5573 01bd07fe5b51f50b adresinden alınd 1

www.metmuseum.org. . May1s 02, 2021 tarihinde The Met: https://www.metmuseum.org/exhibitions/listings/2012/byzantiumand-islam/blog/characters/posts/abd-al-malik adresinden alınd1

www.zeno.ru. Haziran 1, 2021 tarihinde ZENO.RU - Oriental Coins Database: https://www.zeno.ru/showgallery.php?cat=1024 adresinden alınd 1 